\author{
Magdalena Banaszkiewicz \\ https://orcid.org/0000-0002-4020-6308 \\ Uniwersytet Jagielloński \\ Wydział Studiów Międzynarodowych i Politycznych \\ Instytut Studiów Międzykulturowych \\ m.banaszkiewicz@uj.edu.pl \\ Zbigniew Semik \\ https:/ / orcid.org/0000-0003-1216-5948 \\ Uniwersytet Pedagogiczny w Krakowie \\ Instytut Historii i Archiwistyki \\ z.semik@gmail.com
}

\title{
SCHRONY W NOWEJ HUCIE JAKO KŁOPOTLIWE DZIEDZICTWO: POMIĘDZY EDUKACJĄ A ROZRYWKĄ
}

\begin{abstract}
Abstrakt: W artykule podjęto próbę ukazania, w jaki sposób przestrzeń dziedzictwa Nowej Huty ulega stopniowej transformacji pod wpływem ruchu turystycznego. Przykładem, który zostanie przeanalizowany, jest projekt nowej trasy turystycznej, prezentującej schrony w Nowej Hucie. Kontekstem do rozważań będzie koncepcja edutainment, czyli forma edukacji poprzez rozrywkę. Rozważania będą oparte na tezie, że włączanie elementów rozrywki w proces interpretacji kłopotliwego dziedzictwa stanowi rozwiązanie, które ułatwia dostrzeżenie ambiwalencji wynikających ze złożonej przeszłości i tym samym przyczynia się do bardziej pogłębionego rozumienia, a w konsekwencji także do akceptacji dziedzictwa.
\end{abstract}

Słowa kluczowe: dziedzictwo, turystyka, edukacja, Nowa Huta, schrony.

\section{WSTĘP}

Przypadek Nowej Huty znalazł się w ostatnich latach $\mathrm{w}$ orbicie zainteresowania badaczy reprezentujących różne dyscypliny wiedzy i koncentrujących się na różnych aspektach życia w tej dzielnicy (Gądecki, 2012; Golonka-Czajkowska, 2013; Poźniak, 2014). Nicią łączącą większość studiów nad Nową Hutą jest refleksja nad aktualną sytuacją, ale snuta w kontekście przeszłości. Autorzy szczególnie podkreślają, jak trudno badać dzisiejszą Nową Hutę bez odwołania do historii, która wdziera się w teraźniejszość, determinując losy ludzi i miejsc. W niniejszym artykule zostanie podjęta próba ukazania, w jaki sposób przestrzeń dziedzictwa Nowej Huty ulega stopniowej transformacji pod wpływem ruchu turystycznego. Ze względu na specyficzną przeszłość dzielnica może być określana mianem kłopotliwego dziedzictwa. To nie zmienia jednak faktu (a może właśnie stanowi główną przyczynę tego), że do Nowej Huty z roku na rok przybywa coraz więcej turystów. W efekcie modyfikacji i rozbudowie ulega oferta kulturalna i turystyczna, kierowana zarówno do turystów, jak i do mieszkańców. Przykładem, który zostanie przeanalizowany, jest projekt nowej trasy tury- stycznej, prezentującej schrony w Nowej Hucie. Kontekstem do rozważań będzie koncepcja edutainment, czyli forma edukacji poprzez rozrywkę. Autorzy postarają się wykazać, że włączanie elementów rozrywki w proces interpretacji kłopotliwego dziedzictwa stanowi rozwiązanie, które ułatwia dostrzeżenie ambiwalencji wynikających ze skomplikowanej przeszłości i tym samym przyczynia się do bardziej pogłębionego rozumienia, a w konsekwencji także akceptacji dziedzictwa.

\section{NOWA HUTA JAKO KŁOPOTLIWE DZIEDZICTWO}

Nowa Huta, będąca obecnie najbardziej wysuniętą na wschód i najliczniej zamieszkałą dzielnicą Krakowa, powstała w następstwie wybudowania w latach 50. XX w. Huty im. Lenina. Paradoksalnie, chociaż Nowa Huta miała być wcieleniem idei perfekcyjnego miasta socrealistycznego, w którym ludzie żyją i pracują, by budować „Świetlaną przyszłość" socjalistycznej utopii, dzielnica ta 
stała się jedną z najbardziej zbuntowanych ideologicznie części Krakowa, jako że jej mieszkańcy walczyli w latach 60. XX w. przeciwko polityce ateizacji, a w latach 80 . włączali się na masową skalę w ruch Solidarności (Dzieszyński, Franczyk, 2010; Jagło, Lempart, 2013; Lebow, 2013). Po upadku socjalizmu Nowa Huta musiała zmierzyć się z całkowicie nową - zarówno z perspektywy ekonomicznej, jak i społecznej - sytuacją (Poźniak, 2014; Stenning, Smith, Rochovská, Świątek, 2010). Jednocześnie, zbudowana jako sztandarowe socjalistyczne miasto (Majewska, 2007), była nadal postrzegana $\mathrm{w}$ kategorii symbolu poprzedniej epoki. Właśnie jako taki, w nowej rzeczywistości demokracji i wolnego rynku, w znacznej mierze była łączona $\mathrm{z}$ negatywnym stereotypem miejsca ponurego, niebezpiecznego i bez perspektyw.

Na ten ambiwalentny stosunek do Nowej Huty składało się kilka czynników, które z czasem stały się swoistymi mitami. Ich genezy upatrywać należy w samych początkach istnienia dzielnicy. Pierwszym $\mathrm{z}$ nich był fakt, że Nowa Huta została zaprojektowana jako oddzielne miasto, co uznawano za próbę odebrania Krakowowi należnej mu rangi. Wiązało się to również ze składem demograficznym nowych mieszkańców, wśród których przeważała ludność napływowa pochodzenia chłopskiego i robotniczego, co przełożyło się na wizerunek Huty jako miejsca niebezpiecznego, w którym często dochodzi do aktów przemocy. Kolejną kwestią przyczyniającą się do negatywnego postrzegania Nowej Huty stało się samo założenie urbanistyczne. Chociaż układ urbanistyczny jest doskonałym przykładem architektury okresu socrealizmu, był uznany za typowy "styl radziecki”. Mimo że projekt zabudowy został zaproponowany przez bardzo utalentowanego krakowskiego architekta T. Ptaszyckiego, który czerpał inspirację ze znanych rozwiązań przestrzennych, takich jak: plac św. Piotra, plac Vendome czy Paryż po przebudowie przeprowadzonej przez G. Haussmanna (Klaś, 2018; Klimek, 2013), jego koncepcja była traktowana jako narzucona przez obcego najeźdźcę, a przez to estetycznie odrzucana przez wielu mieszkańców. Co więcej, szczególnie w okresie transformacji oskarżano kombinat o wzrastające zanieczyszczenie zarówno w bliskiej, jak i dalekiej odległości.

Wszystkie wyżej wymienione kwestie miały swoje zakotwiczenie w rzeczywistości, jednak skala, do jakiej zostały rozdmuchane, znacznie przerosła problemy leżące $\mathrm{u}$ ich podstaw. Z tego względu dzisiejsze postrzeganie Nowej Huty jako dziedzictwa jest silnie naznaczone mitami, wokół których ukształtowała się narracja o dzielnicy. Niewątpliwie spośród wielu zasobów przeszłości tylko niewielka część uznawana jest za dziedzictwo. Kształtowanie się dziedzictwa jest związane z procesem negocjowania, kwestionowania i uwzględniania różnych działań podejmowanych przez uczestników debaty. Nawet jeśli układ urbanistyczny No- wej Huty został uznany przez miasto za reprezentacyjny przykład socrealistycznej urbanistyki w Polsce, nie oznacza to, że ludzie (np. mieszkańcy Krakowa) automatycznie przyznali mu status dziedzictwa (Klaś, 2016; Salwiński, Sibila, 2008).

Dziedzictwo może być postrzegane jako forma społecznej, kulturowej lub zbiorowej pamięci, która bezpośrednio identyfikuje się poprzez koncepcję posiadania przeszłości (Smith, 2006). W społeczeństwach, w których kontestuje się przeszłość, narracja o dziedzictwie jest daleko od jednoczenia ludzi (Tunbridge, Ashworth, 1996), dlatego może najtrafniejszym terminem, który mógłby zostać zastosowany do opisu Nowej Huty, jest „kłopotliwe dziedzictwo”, określane przez Ashwortha jako "brak harmonii czasu i przestrzeni pomiędzy ludźmi a ich dziedzictwem" (Ashworth, 2002, s. 363).

Dysonans ten, jak zauważają Tunbridge i Ashworth (1996), ujawnia się w dwóch sytuacjach. Po pierwsze, gdy dominująca narracja nie współgra z interpretacjami różnych grup interesów, gdyż pomija aspekty uważane przez nie za ważne lub uwypukla te, którym nie powinno się nadawać tak istotnego znaczenia. Jak zauważają Smith i Hall (2006), większość wspólnego dziedzictwa Europy Środkowo-Wschodniej można uznać za kontestowane pole bitwy, na którym polityczne, ekonomiczne, społeczne i kulturowe priorytety tkwią w klinczu. Druga sytuacja wzbudzająca dysonans zachodzi, gdy następuje komercjalizacja dziedzictwa, powodująca jego transformację w produkt na sprzedaż. W tym przypadku fundamentalnym katalizatorem jest ruch turystyczny, prowadzacy do nadania dziedzictwu charakteru atrakcji turystycznej. Zarówno materialne, jak i niematerialne dobra kultury stają wówczas w obliczu realiów rynkowych, w których etyka zrównoważonego rozwoju nierzadko ustępuje pola doraźnemu merkantylizmowi. Należy jednak zauważyć, że charakterystycznym zjawiskiem jest dostrzeżenie wartości własnego dziedzictwa kulturowego w momencie, gdy wzbudza ono zainteresowanie przybywających doń turystów.

Wydaje się, że taka właśnie zależność daje się zaobserwować od kilku lat w Nowej Hucie, którą coraz liczniej zaczęli zwiedzać turyści, głównie zagraniczni. Niewątpliwie istotnym czynnikiem przyczyniającym się do wzrostu popularności Nowej Huty jest bardzo konkretny produkt turystyczny, tzw. wycieczki komunistyczne (Knudsen, 2010; Whigham, 2014). Jak zauważa Banaszkiewicz (2018), początkowo wycieczki wzbudzały bardzo mieszane uczucia wśród mieszkańców. Wielu spośród nich, ze względu na specyficzną narrację przewodników (z dużą dawką ironii, bazującą na anegdotach i traktującą przeszłość z chłodnym dystansem), czuło się wydziedziczonych z własnego dziedzictwa. Przede wszystkim jednak, poważne wątpliwości wzbudzała przyjęta przez crazy guides (szalonych przewodników) forma zwiedzania, dalece różna od kla- 
sycznej usługi przewodnickiej i dryfująca w stronę minispektaklu. W czasie gdy crazy guides zaczynali, ów element rozrywki, traktowanej jako część składowa procesu poznawczego, był w przestrzeni lokalnych usług turystycznych radykalną nowością. Obecnie w coraz większej liczbie produktów turystycznych występują elementy rozrywki mające na celu zaspokojenie potrzeby przyjemności.

\section{EDUKACJA I ROZRYWKA W TURYSTYCE}

Próbę holistycznego wyjaśnienia fenomenu turystyki sprowadzić można do dwóch koncepcji. Pierwsza z nich, ujmująca turystykę jako "świeckie pielgrzymowanie”, zakłada, że motywację turysty stanowi poszukiwanie sensu, odkrywanie autentyczności i transformacja podmiotu doświadczającego inności świata podczas podróży. Druga teoria tłumaczy powody wyruszenia w podróż zgoła odmiennie, upatrując ich w poszukiwaniu przyjemności i rozrywki, umożliwiających turystom oderwanie się od codziennych trosk i obowiązków (Boorstin, 1964; Pfaffenberger, 1983). Koncepcja ta stanowi odwołanie do korzeni humanistycznej refleksji nad kondycją człowieka, ujmowanego jako istota pracująca. Jak pisał Okoń, odwołując się do poglądów Arystotelesa: „Zabawa jako wypoczynek jest konsekwencją pracy jako zmęczenia. Gdzie jest praca, tam musi być zabawa, bo zmęczenie wymaga wypoczynku [...]" (Okoń, 1995, s. 60). Czas wolny, przeznaczony chociażby na podróżowanie, stoi w opozycji wobec aktywności zawodowej, a zatem ma dawać przyjemność niemożliwą do osiągnięcia podczas pracy, utożsamianej z obowiązkiem, powagą i odpowiedzialnością. Zdaniem Huizingi (1997), autora klasycznego ujęcia człowieka jako homo ludens - istoty bawiącej się, owa „niepowaga”, będąca swobodnym działaniem, jest właśnie kwintesencją zabawy.

O ile jednak w koncepcji Huizingi zabawa może być sprawą śmiertelnie poważną i stanowi po prostu właściwość kultury, która nie może ulegać wartościowaniu jako dobra czy zła, o tyle rozrywka, czyli upraszczając, zabawa będąca produktem w kulturze konsumpcyjnej, grozi infantylizacją dorosłych, gdyż skala zjawiska przybiera zatrważające rozmiary. Jak twierdzą Combs (2000) oraz Postman (2000), wchodzimy obecnie w nową fazę historii ludzkości, do tego stopnia przenikniętą przez zabawę, że można ją określić mianem świata zabawy. Rozrywka jest cechą dystynktywną kultury masowej, będącej jednocześnie kulturą konsumpcyjną (Kantor, Paleczny, Banaszkiewicz, 2011; Paleczny, Kantor, Banaszkiewicz, 2012). Nie ma zatem kultury konsumpcyjnej bez rozrywki. Innymi słowy, turyści są w tym ujęciu hedonistycznie zorien- towanymi konsumentami, żądnymi nieustannie nowych przeżyć, stymulujących ich emocje (Bauman, 1996; Salazar, 2010).

Turystyka oparta na produktach dających przyjemność i relaks, określona mianem $3 S$ - sun, sea, sand (słońce, morze, piasek), stała się desygnatem najpopularniejszych masowych podróży, czyli odpoczynku w kurortach w ciepłych krajach. Jednak wraz z lawinowym rozwojem turystyki w ostatnim ćwierćwieczu nastąpiła stopniowa reorientacja, wpisująca się zresztą w globalne trendy konsumpcji, potrzeb turystów, a co za tym idzie - oferty. Przesunięcie akcentu z produktu (posiadanie rzeczy) na doświadczenie (kolekcjonowanie przeżyć) (Pine, Gilmore, 1999), które stało się podstawą konsumpcji XXI w., znalazło swoje odzwierciedlenie w podróżowaniu (Urry, Larsen, 2011). Za poręczniejszą metaforę, stosowaną coraz częściej zamiast 3S, zaczęto uznawać 3E, będące skrótem od entertainment, education, excitement (rozrywka, edukacja, ekscytacja). Odejście od turystyki masowej, bazującej na walorach środowiskowych, i w konsekwencji zwrot $\mathrm{ku}$ turystyce indywidualnej, opartej na aktywnym zaangażowaniu turysty i zwiększającym się udziale produktu turystycznego w kategorii turystyki kulturowej, to charakterystyczny trend ostatnich lat obserwowany w skali globalnej. Rozrywka nie została porzucona, lecz stanęła $\mathrm{w}$ triadzie $\mathrm{z}$ education, a zatem walorem poznawczym, i excitement, czyli przeżyciem, silnym i pozytywnym bodźcem emocjonalnym (Robinson, Picard, 2016).

Podkreślanie korelacji pomiędzy skutecznością edukacji i obecnością w procesie poznawczym elementów rozrywki, nie jest bynajmniej zjawiskiem nowym, aczkolwiek w ostatnich dekadach zyskuje coraz bardziej na znaczeniu. Dostrzec je można w miejscach dziedzictwa, które są dostosowywane do potrzeby rozrywki u turystów, jak również w muzeach. Zwłaszcza te ostatnie przechodzą znaczącą transformację, starając się dostosować ofertę do najnowszych trendów w kulturze (Caulton, 2006; Gawel, Kostera, 2018; Hooper-Greenhill, 2007; Parry, 2013). Coraz większy nacisk kładzie się zatem na funkcję edukacyjno-wychowawczą, realizowaną w duchu głębszego angażowania odbiorcy w aktywną percepcje przestrzeni wystawienniczej. Cel ten zostaje osiągnięty za pomocą całej palety rozwiązań multimedialnych, oddziaływania na wszystkie zmysły, a także dywersyfikacji narracji muzealnej, dzięki czemu możliwy jest bardziej zindywidualizowany przekaz dostosowany do subiektywnych potrzeb zwiedzającego. Jakość oferty jest oczywiście bardzo zróżnicowana, począwszy od "gadżeciarskich” rozwiązań, które stanowią jedynie ozdobnik, nie przyczyniając się do głębokiego zrozumienia prezentowanych treści, skończywszy na dobrze przemyślanych koncepcjach, znacząco poprawiających stopień percepcji odbiorcy. 
Warto jednak pamiętać, że nie tylko scenariusze wystaw czy projekty „uludycznienia” przekładają się na skuteczność procesu edukacyjnego. Jego nieodzownym elementem jest spektrum motywacji, którymi kieruje się odbiorca (zwiedzający, widz, turysta). Jak pokazują badania przywoływane przez Falka i Dierking lepsze rezultaty poznawcze osiąga się, gdy zwiedzający muzeum cechuje się wysokim poziomem motywacji:

Zgodnie z przewidywaniami, osoby o silnej motywacji edukacyjnej uzyskiwały zdecydowanie lepsze wyniki w procesie poznawczym niż ci, których cechowała słaba motywacja. Jednak, co nie było do tego stopnia oczekiwane, podobną zależność znaleziono pomiędzy osobami o silnej motywacji do zabawy, niezależnie od poziomu motywacji edukacyjnej (Falk, Dierking, 2000, s. 79).

Jak się okazuje, nastawienie "prorozrywkowe” skutkuje zatem lepszymi rezultatami edukacyjnymi. Kontynuacja tych rozważań wkracza już w przestrzeń badań psychologicznych, których przywoływanie znacznie wychodziłoby poza ramy niniejszego artykułu, niemniej warto zauważyć, że pejoratywne wartościowanie rozrywki jako "gorszej formy” zabawy wymaga większego zniuansowania, nieopartego na dychotomicznej generalizacji.

Szczególnie trudnym wyzwaniem jest natomiast uwzględnienie w prezentowaniu kłopotliwego dziedzictwa rozwiązań umożliwiających czerpanie przyjemności z zabawy. Wynika to z faktu, że takie dziedzictwo nie podlega harmonijnej interpretacji. Ambiwalentność związana $\mathrm{z}$ jego postrzeganiem wymaga od zarządzających szczególnej delikatności i wyczucia, tak, by w imię dążenia do „uprzyjemnienia” doświadczania dziedzictwa narracja o przeszłości nie była jednostronna, subiektywna oraz zbyt uproszczona. Na przykładzie projektowanej trasy turystycznej, poświęconej nowohuckim schronom z okresu zimnej wojny, autorzy niniejszego artykułu postarają się zilustrować, jak jej twórcy dążą do połączenia elementów edukacji i zabawy.

\subsection{SCHRONY W NOWEJ HUCIE}

Powstanie schronów w Polskiej Rzeczpospolitej Ludowej było związane z utrzymującym się stanem napięcia między państwami skupionymi wokół Związku Radzieckiego a Stanami Zjednoczonymi, które przeszło do historii pod nazwą zimnej wojny. Wydarzenia tego czasu, takie jak kryzys berliński z lat 1948-1949 czy wojna koreańska z lat 1950-1953, generowały wzrost wydatków na zbrojenia w państwach, które mogły być zaangażowane w ewentualny konflikt (w ich gronie znajdowała się również Polska), ponadto wymuszały inwestycje mające na celu ochronę ludności cywilnej (Holzer, 2012).
Decyzję o stworzeniu schronów w Polskiej Rzeczpospolitej Ludowej podjęto na poziomie krajowym 10 października 1952 r. na mocy uchwały Rady Ministrów. Miały one zostać zbudowane na 72 obszarach kraju, wytypowanych jako najbardziej prawdopodobne cele potencjalnego ataku. Ze względu na duże koszty związane z konstrukcją budowli ochronnych 15 lutego 1958 r. kolejną uchwałą zmniejszono liczbę obszarów do 30, 28 września 1960 r. zaś całkowicie zaniechano tworzenia schronów w nowo powstałych budynkach (Mierzwa, Semik, 2015).

Jednym z wytypowanych obszarów, z racji swojego strategicznego znaczenia, była Nowa Huta. W latach 1953-1960 na terenie tej dzielnicy powstało ok. 250 schronów. Mieściły się zarówno pod budynkami mieszkalnymi, jak i pod obiektami użyteczności publicznej, takimi jak: kino, teatr czy szpital, a także pod zakładami przemysłowymi. Dwa schrony znajdowały się również w podziemiach kina Światowid, późniejszej siedzibie Muzeum PRL-u (Mierzwa, 2015).

\subsection{MITY DOTYCZACE SCHRONÓW}

Wbrew popularnej i wielokrotnie powielanej nowohuckiej legendzie miejskiej schrony nie chroniły przed wybuchem ładunku nuklearnego. Były przeznaczone do ochrony przed bronią konwencjonalną. Na etapie planowania infrastruktury schronowej na terytorium Polskiej Rzeczpospolitej Ludowej na początku lat 50. Istniała świadomość zagrożenia bombą atomową. Decydenci zdawali sobie sprawę, że taka broń znajdowała się zarówno w arsenałach Związku Radzieckiego, jak i Stanów Zjednoczonych, jej liczebność i środki przenoszenia natomiast w owym czasie nie były aż tak zaawansowane, aby brać pod uwage zmasowany atak. Sytuacja zmieniła się w ciągu dekady, czego skutkiem było wydanie w 1959 r. nowych wytycznych budowy schronów, uwzględniających również to zagrożenie. W Nowej Hucie powstały $\mathrm{w}$ tym czasie zmodyfikowane budowle ochronne, zabezpieczające przed niektórymi następstwami wybuchu nuklearnego, natomiast niezapewniające bezpieczeństwa w razie bezpośredniego ataku.

Kolejną legendą miejską jest opowieść o sieci korytarzy, biegnących w podziemiach dzielnicy i łączących schrony. Prawdopodobnie do powstania tej opowieści przyczynił się fakt, że bardzo często korytarze ewakuacyjne wyprowadzane pod poziomem gruntu $\mathrm{z}$ podziemi budynków posiadały jedno wspólne wyjście (tzw. wyłaz) na powierzchnię. Ekstremalną wersją wspomnianej legendy jest historia o podziemnym, tajnym korytarzu, łączącym schron w obecnym Muzeum PRL-u i Centrum Administracyjnym dawnej Huty im. Lenina, które znajdują się w odległości paru kilometrów (Mierzwa, Semik, 2015). 
Dysonanse związane z akceptacją schronów jako atrakcji turystycznej opierają się przede wszystkim na popularnym przekonaniu, że nie mają one wiele wspólnego z prawdą historyczną. Chociaż mity nowohuckie stymulują postrzeganie schronów, nie są podstawową osią napięcia, które powstaje w związku z tworzeniem trasy turystycznej. Pierwsza kontrowersja jest konsekwencją stosunku do dziedzictwa przemysłowego per se. Akceptacja jego symbolicznej wartości nadal jest przedmiotem wielu debat, w których uczestniczą przedstawiciele władz lokalnych / mieszkańcy, niekoniecznie postrzegający je jako obiekty materialne zasługujące na ochronę i rozwój (zob. Gaweł, 2014; Xie, 2015). Po drugie sceptycyzm wobec schronów wynika z kwestii praktycznego zarządzania tym zasobem dziedzictwa: schrony znajdują się pod budynkami, które nadal pełnią różne funkcje (w przypadku Nowej Huty są to: bloki mieszkalne, szpital czy biura administracyjne kombinatu), co wiąże się z koniecznością harmonizowania działań mających na celu zaspokajanie potrzeb różnych interesariuszy.

\subsection{TRASA TURYSTYCZNA}

Muzeum PRL-u (od 1 marca 2019 r. wchodzące w skład Muzeum Krakowa pod nazwą Muzeum Nowej Huty; zob. Muzeum PRL-u, Muzeum Historyczne Miasta Krakowa), mierząc się z wyżej wymienionymi mitami, zorganizowało w $2015 \mathrm{r}$. w podziemiach socrealistycznego budynku dawnego kina Światowid wystawę "Atomowa groza. Schrony w Nowej Hucie", na której została zaprezentowana historia schronów oraz ich propagandowa i zimnowojenna otoczka (Nuclear threat. Shelters in Nowa Huta, 2015). Sama instytucja działała od 2013 r. do 2019 r. i była współprowadzona przez Ministerstwo Kultury i Dziedzictwa Narodowego oraz Gminę Miejską Kraków. Muzeum prowadziło działalność wydawniczą (publikując rocznik naukowy "Światowid" oraz katalogi towarzyszące wystawom), edukacyjną (zapraszając zwiedzających do uczestnictwa w debatach, wykładach, dyskusjach, spotkaniach i promocjach książek) oraz wystawienniczą (organizując i sprowadzając ekspozycje pomagające zrozumieć różne aspekty funkcjonowania systemu komunistycznego zarówno w Polsce, jak i na świecie). Obecnie Muzeum nie posiada wystawy stałej - zostanie ona zrealizowana równocześnie z pełną adaptacją budynku dawnego kina do celów muzealnych (zob. Muzeum PRL-u).

Aby w pełni wykorzystać potencjał znajdujących się na terenie dzielnicy budowli ochronnych, na zlecenie Gminy Miejskiej Kraków Muzeum koordynuje powstawanie trasy turystycznej (rys. 1), która ukaże schrony w szerszym kontekście. Planowana trasa za- kłada udostępnienie zwiedzającym czterech lokalizacji - trzech znajdujących się na osiedlu Szkolnym oraz jednej na osiedlu Krakowiaków (lokalizacja rezerwowa). W pierwotnej koncepcji nacisk kładziono głównie na rekonstrukcję wnętrz oraz ukazanie dawnych funkcji udostępnianych w ramach trasy schronów - standardowy schron dla mieszkańców, improwizowane ukrycie, schron doposażony, mający zabezpieczać przed niektórymi skutkami wybuchu nuklearnego, oraz punkt medyczny (Pasternak, 2019). W scenariuszu, który powstał na podstawie tej koncepcji, postanowiono spojrzeć na tematykę schronową $\mathrm{z}$ odmiennej perspektywy, z zachowaniem wyżej wymienionych lokalizacji.

Przy tworzeniu scenariusza autorzy (Katarzyna Zarzycka i pracownicy Muzeum PRL-u) oparli się na teorii interpretacji dziedzictwa Tildena (1957), które jest narzędziem dającym możliwość poznania i zrozumienia dziejów schronów oraz odniesienia ich do współczesności, a także do osobistych doświadczeń zwiedzających. W założeniu autorów wystawa ma składać się z modułów (podzielonych na poszczególne segmenty i sceny) umieszczonych $\mathrm{w}$ czterech lokalizacjach z opcją rozszerzenia na kolejne wnętrza "pod" Nową Hutą. $Z$ jednej strony moduły te będą stanowiły całość funkcjonującą pod tytułem "Schrony Nowej Huty - dziedzictwo zimnej wojny", z drugiej strony jednak wystawę będzie można traktować jako zbiór elementów układanki z możliwością wyboru przez turystów zwiedzanej lokalizacji, zgodnej z ich oczekiwaniami i zainteresowaniami (Zarzycka, 2017).

Wśród najważniejszych celów obranych przez twórców scenariusza w kontekście powstającej trasy wymieniono: popularyzację schronów jako elementu dziedzictwa kulturowego Nowej Huty związanego z zimną wojną; zaprezentowanie historii ich powstawania; konstrukcję atrakcyjnej oferty spędzenia czasu wolnego, prowokującej do aktywności intelektualnej; zachęcenie zwiedzających do porównania przeszłości ze współczesnością poprzez szukanie analogii; stworzenie przekazu trafiającego do różnych grup odbiorców oraz intensyfikację ruchu turystycznego w obrębie Nowej Huty.

W zrealizowanej dotychczas części trasy, zlokalizowanej na osiedlu Szkolnym 37, znalazł się moduł zatytułowany "Stan zagrożenia”. W przestrzeni schronu znajdującego się pod nowohuckim Zespołem Szkół Mechanicznych nr 3 zostały umieszczone treści dotyczące potrzeby schronienia, którą odczuwają zarówno ludzie, jak i zwierzęta („Potrzeba schronienia”). Tematyka przedstawiona jest za pomocą dioram, ilustrujących niektóre ze sposobów chronienia się tych istot. Zadaniem przewodników oprowadzających po wystawie jest nawiązanie dialogu ze zwiedzającymi, którzy na bazie swojej wiedzy wymieniają różne sposoby reakcji zwierząt na sytuacje zagrożenia i strategie 


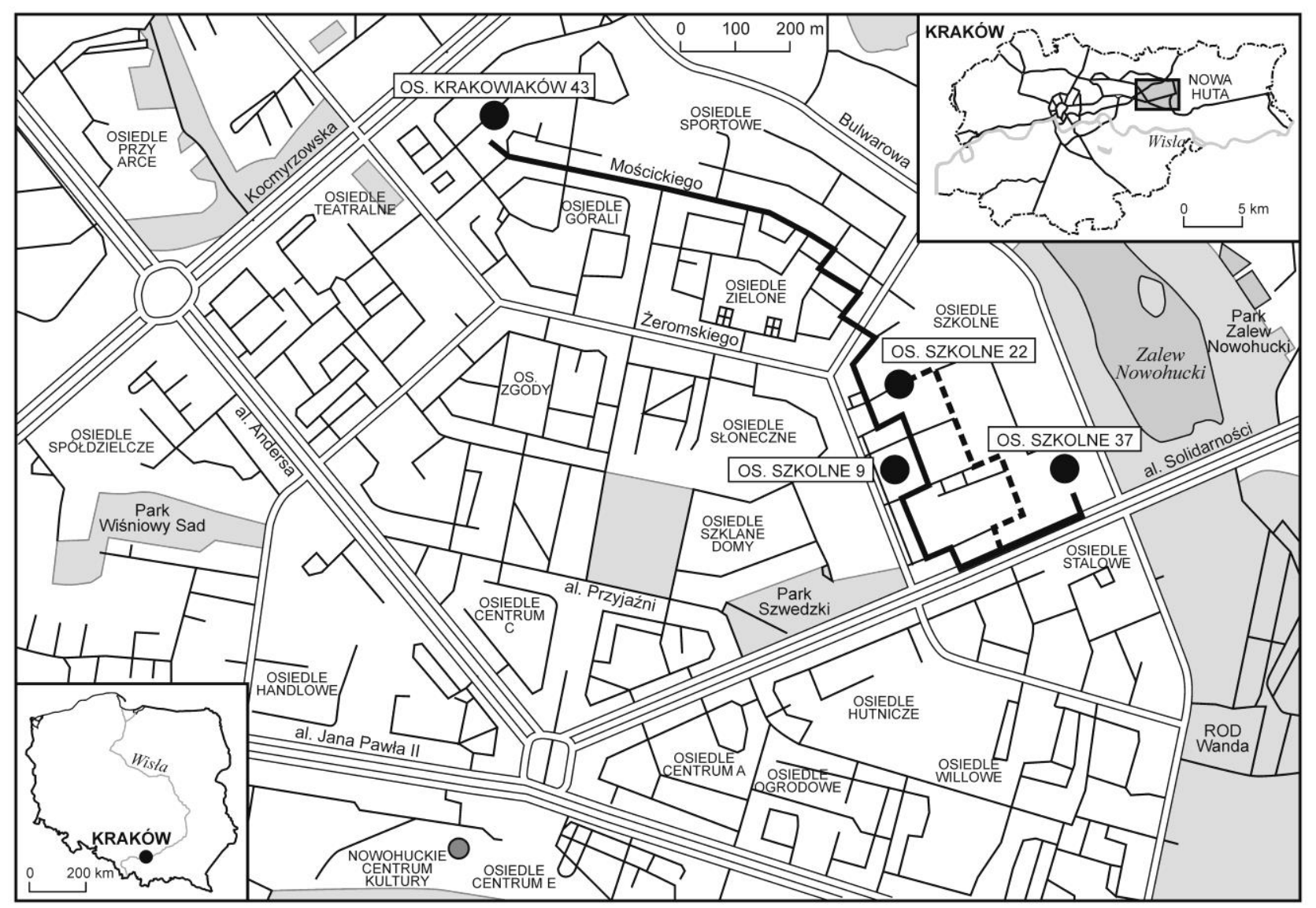

Rys. 1. Schrony znajdujące się w Nowej Hucie Źródło: opracowanie własne

przetrwania obserwowane w naturze (mimikra itp.). Wystawa obejmuje także narrację zatytułowaną "Schrony na świecie", która dotyczy historii budownictwa schronowego i obejmuje okres od I wojny światowej do czasów współczesnych. W narracji tej przedstawiono również nowoczesne realizacje. Treści tej części ekspozycji ilustrowane są za pomocą zdjęć oraz filmu animowanego, który w przystępny i atrakcyjny sposób przybliża dzieje konstrukcji schronowych. $\mathrm{Na}$ wystawie została umieszczona również makieta modelowego schronu z lat 80., zabezpieczającego przed niektórymi skutkami wybuchu nuklearnego (scena „Makieta”). Ostatnim elementem ekspozycji jest sala zatytułowana „Historia na szczęście niedokończona”, zawierająca wybór zachęcających do refleksji pytań, które pomagają zwiedzającym wczuć się $\mathrm{w}$ sytuację funkcjonowania w klaustrofobicznym schronie.

W planowanym centrum trasy na osiedlu Szkolnym 22 znajdzie się moduł wystawy zatytułowany "Schrony w Nowej Hucie. Duch miejsca, duch czasu”. Zostanie on podzielony na trzy segmenty: "Nowa Huta: duch miejsca”, "Zimna wojna: duch czasu” oraz „Do schronu!". Celem pierwszej sceny pierwszego segmentu („Nowa Huta intro") będzie wprowadzenie turystów w genius loci Nowej Huty. W scenie „Miasto start” turysta zdobędzie wiedzę na temat sytuacji Polski po II wojnie światowej i historii planu sześcioletniego, którego kluczowym elementem była Nowa Huta. W kolejnych scenach zostaną zaprezentowane: propaganda lat 50. towarzysząca budowie schronów, plany urbanistyczne dzielnicy i ich twórcy oraz architektura Nowej Huty ze szczególnym uwzględnieniem stylu socrealistycznego. Opisana wyżej część ekspozycji zostanie uzupełniona o projekcję filmu Kierunek: Nowa Huta oraz makiety ukazujące zarówno przygotowany, jak i zrealizowany projekt dzielnicy. W scenie pierwszej drugiego segmentu (,Żelazna kurtyna - symbol zimnej wojny") zarysowane zostanie natomiast zimnowojenne tło z tytułową żelazną kurtyną oraz implikacjami podziału świata na dwa bloki. Zapoznając się ze sceną drugą, zwiedzający pozna najważniejsze wydarzenia zimnej wojny, usytuowane na osi czasu. W scenie trzeciej zaś („Codzienność w cieniu zimnej wojny") będzie miał szansę przyjrzeć się nowohuckiej codzienności w cieniu potencjalnego konfliktu. W segmencie trzecim, zawierającym stanowiska "Schrony pod Nową Hutą" i „Konstrukcja schronu”, zostaną umieszczone informacje o sieci budowli ochronnych pod terenem dzielnicy oraz o szczegółach technicznych tych 
konstrukcji. „Strach” ma z kolei na celu uzmysłowienie zwiedzającym poczucia lęku towarzyszącego ludziom po obu stronach żelaznej kurtyny.

Moduł numer trzy („Wokół atomu”) znajdzie się w schronie na osiedlu Szkolnym 9. W scenach tam umieszczonych (,Atom - wróg czy przyjaciel” i ,"Era nuklearna w popkulturze") będą zaprezentowane dwa aspekty wykorzystania atomu - $\mathrm{z}$ jednej strony używania jako elementu destrukcyjnej broni nuklearnej, $\mathrm{z}$ drugiej strony zaś zastosowania go np. $\mathrm{w}$ walce $\mathrm{z}$ nowotworami. W scenach zostaną pokazane także wątki popkulturowe związane $\mathrm{z}$ bronią nuklearną - $\mathrm{w}$ muzyce, filmie, książkach i wielu innych. $W$ rezultacie energia nuklearna będzie prezentowana zwiedzającym i poddawana pod dyskusję $\mathrm{z}$ różnych perspektyw, nieograniczających się jedynie do cienia zimnej wojny.

Ostatni z planowanych modułów to „Kruchy pokój, kruche bezpieczeństwo". Pierwsza scena - „Tryb awaryjny" - będzie próbą zastanowienia się nad zachowaniem ludzi w sytuacjach od prostej awarii prądu aż po kataklizm na wielką skalę. „Obrona ludności" to scena, która zostanie poświęcona dziejom obrony cywilnej, a także współczesnemu zarządzaniu kryzysowemu. W „Miejskich mitach” o schronach w Nowej Hucie zostaną zweryfikowane tzw. urban legends na temat infrastruktury schronowej, natomiast "Lamus historii?" to scena poświęcona refleksji na temat stanu napięcia wciąż obecnego na świecie, mimo obwieszczonego końca zimnej wojny oraz zagrożenia płynącego $\mathrm{z}$ istniejących nadal arsenałów broni nuklearnej.

Pomocą w zrozumieniu i przyswojeniu treści mają być oryginalne przedmioty z czasów konstrukcji i użytkowania schronów oraz prawdziwe części wyposażenia, uzupełniane przez multimedia, gry edukacyjne, a także zdjęcia czy plakaty, umożliwiające wypracowanie ścieżki zachowującej zarówno walory rozrywki, jak i edukacji.

\section{PODSUMOWANIE}

Nowa atrakcja turystyczna, która pojawiła się w przestrzeni Nowej Huty na początku 2019 r., będzie rozbudowywana w kolejnych latach (rys. 1 ilustruje planowaną trasę łączącą cztery obiekty dziedzictwa). Po zaadaptowaniu prawdziwych schronów, których przestrzeń została zmodyfikowana dzięki specjalnej ekspozycji, możliwe stało się osiągnięcie podwójnego wymiaru autentyczności - obiektywnej/zimnej oraz subiektywnej/gorącej (Selwyn, 1996). Oryginalne wnętrza zakotwiczone $\mathrm{w}$ dziejach dzielnicy gwarantują obiektywną wartość świadectwa przeszłości, podczas gdy narracja ekspozycji uzupełnia ją, otwierając hory- zont emocjonalnego doświadczenia autentyczności gorącej. Istotnie, to podejście wpisuje się $\mathrm{w}$ podstawowe założenia ekonomii doświadczeń (Pine, Gilmore, 1999; Urry, Larsen, 2011), która w centrum wymiany stawia nie produkty czy usługi, lecz przeżycia. Za pomoca edukacji multisensorycznej, angażującej wizualną, audialną, kinestetyczną oraz dotykową stymulację, jak również dzięki wykwalifikowanym przewodnikom, których rolą jest wspieranie procesu interpretacyjnego, zwiedzający nie tylko doświadczą unikatowego przeżycia, lecz przede wszystkim w atmosferze zabawy pogłębią swoją wiedzę i rozwiną umiejętności. Projekty edukacyjne, których celem jest wieloperspektywiczna interpretacja dziedzictwa (szczególnie kłopotliwego, z jego "chropowatością" i trudnościami w wyjaśnianiu), stanowią podstawę tworzenia przestrzeni dialogu opartego na rozumieniu tego, jak złożona jest otaczająca rzeczywistość. Jak podkreślał Tilden w swoich sześciu zasadach interpretacji:

\section{Interpretacja jest sztuką łączącą wiele dziedzin, choć prezentowane materiały mogą dotyczyć świata nau- ki, historii czy architektury. Każdej zaś sztuki do pewnego stopnia można się nauczyć. Głównym ce- lem interpretacji nie jest nauczanie, lecz prowoko- wanie do myślenia (Tilden, 1957, s. 9).}

Nawet jeśli konsumpcja doświadczeń okazuje się dużym wyzwaniem dla współczesnych muzeów, nie jest to zwykła wojna pomiędzy niską rozrywką a edukacyjny oświeceniem. Istotę debaty stanowi bowiem otwartość na prowokacyjną naturę interpretacji. Pozwolenie ludziom na doświadczanie dziedzictwa $\mathrm{w}$ ich własny, indywidualny, subiektywny sposób oznacza akceptację faktu, że stają się oni performatywnymi współtwórcami tej spuścizny, nie tylko zwiedzającymi, czy nawet jej uczestnikami. Wynika to z dwóch założeń, które również chcieli naświetlić autorzy niniejszego tekstu w kontekście trasy turystycznej schronów Nowej Huty. Po pierwsze jest to raczej strategia zachęcania do dyskusji niż zapewniania gotowych wyjaśnien. Zarówno materiały wizualne, jak i prezentowane artefakty czy towarzysząca im narracja są stworzone $w$ taki sposób, by skłaniać zwiedzających do zadawania pytań. Po drugie jest to uniwersalizacja, $w$ tym przypadku problematyki schronów - nieograniczająca ich tylko do pozostałości zimnej wojny, lecz poszerzająca temat poprzez odwołania do historii, różnych kulturowych wymiarów, a nawet środowiska naturalnego. Taka szeroka rama interpretacji funkcji schronów zachęca do pójścia o krok dalej i wyjścia poza dyskusję o przeszłości, w stronę refleksji nad teraźniejszością i przyszłymi zagrożeniami, które płyną z niebezpieczeństw wojen cybernetycznych czy negatywnych konsekwencji zmian klimatycznych. Uświadomienie sobie meandrów przeszłości pozwala lepiej orientować się w teraźniejszości 
i uniknąć pogubienia w przyszłości. Takie inicjatywy, jak trasa poświęcona nowohuckim schronom, są nie tylko atrakcją turystyczną czy historycznym projektem edukacyjnym, ale mogą również odgrywać ważną rolę w kształtowaniu odpowiedzialnych postaw społecznych, odpowiadając na zagrożenia (zarówno realne, jak i wyobrażone) współczesnego świata.

\section{BIBLIOGRAFIA}

Ashworth, G. (2002). Holocaust tourism: The experience of Kraków-Kazimierz. International Research in Geographical and Environmental Education, 11 (4), 363-367.

Banaszkiewicz, M. (2018). Turystyka w miejscach kłopotliwego dziedzictwa. Kraków: Wydawnictwo Uniwersytetu Jagiellonskiego.

Bauman, Z. (1996). From pilgrim to tourist - or a short history of identity. In: S. Hall, P. du Gay (red.), Questions of cultural identity (s. 18-36). London: SAGE Publications.

Boorstin, D. (1964). The image: A guide to pseudo-events in America. New York: Harper \& Row.

Caulton, T. (2006). Hands-on exhibitions: Managing interactive museums and science centres. London: Routledge.

Combs, J.E. (2000). Play world: The emergence of the new ludenic age. Westport: Greenwood Publishing Group.

Dzieszyński, R., Franczyk, J. (2006). Encyklopedia Nowej Huty. Kraków: Wydawnictwo Towarzystwa Słowaków w Polsce.

Falk, J.H., Dierking, L.D. (2000). Learning from museums: Visitor experiences and the making of meaning. Plymouth: Rowman \& Littlefield.

Gądecki, J. (2012). I love NH. Gentryfikacja starej części Nowej Huty. Warszawa: Wydawnictwo Instytutu Filozofii i Socjologii Polskiej Akademii Nauk.

Gaweł, Ł. (2014). Poprzemysłowe dziedzictwo kulturowe a rozwój turystyki. Zastosowanie modelu AUDEE do oceny industrialnych atrakcji turystycznych. Turystyka Kulturowa , 11, 53-67.

Gaweł, Ł., Kostera, M. (eds) (2018). Etnografie instytucji dziedzictwa kulturowego. Kraków: Wydawnictwo Uniwersytetu Jagiellońskiego.

Golonka-Czajkowska, M. (2013). Nowe miasto nowych ludzi. Mitologie nowohuckie. Kraków: Wydawnictwo Uniwersytetu Jagiellońskiego.

Holzer, J. (2012). Europa zimnej wojny. Kraków: Znak.

Hooper-Greenhill, E. (2007). Museums and education: Purpose, pedagogy, performance. London: Routledge.

Huizinga, J. (1997). Homo ludens: zabawa jako źródto kultury. Tłum. M. Kurecka, W. Wirpsza. Warszawa: Wydawnictwo Aletheia.

Jagło, P., Lempart, M. (2013). Nowa Huta 1949+. Kraków: Muzeum Historyczne Miasta Krakowa.

Kantor, R., Paleczny, T., Banaszkiewicz, M. (red.) (2011). Waż $w$ raju. Zabawa $w$ społeczeństwie konsumpcyjnym. Kraków: Wydawnictwo Uniwersytetu Jagiellońskiego.

Klaś, J. (2016). Ochrona dziedzictwa kulturowego Nowej Huty - między teorią a praktyką. W: Ł. Gaweł, W. Pokojska, A. Pudełko (red.), Zarzadzanie dziedzictwem. Problemy, obszary, definicje (s. 254-284). Kraków: Wydawnictwo Attyka.

Klaś, J. (red.) (2018). Nowa Huta. Architektoniczny portret miasta drugiej połowy XX wieku. Kraków: Ośrodek Kultury im. C.K. Norwida.
Klimek, Ł. (2013). Nowa Huta 1949+. Kraków: Muzeum Historyczne Miasta Krakowa.

Knudsen, B. (2010). The past as staged-real environment: Communism revisited in the crazy guides communism tours, Kraków, Poland. Journal of Tourism and Cultural Change, 8 (3), 139-153.

Lebow, K. (2013). Unfinished utopia: Nowa Huta, stalinism, and Polish society, 1949-56. Ithaca-London: Cornell University Press.

Majewska, E. (2007). Nowa Huta as a utopian project: A sketch on political imagination. W: M. Kaltwasser, E. Majewska, J. Szreder (red.), Futuryzm miast przemystowych. 100-lecie Nowej Huty i Wolfsburga (s. 17-25). Kraków: Korporacja Ha!Art.

Mierzwa, T. (2015). Schrony Terenowej Obrony Przeciwlotniczej w Nowej Hucie. Światowid, 2, 141-160.

Mierzwa, T., Semik, Z. (2015). Nuclear threat. Shelters in Nowa Huta. Kraków: Muzeum PRL-u.

Muzeum Historyczne Miasta Krakowa. Pobrane z: https:// www.muzeumkrakowa.pl/oddzialy/muzeum-nowej-huty (14.02.2019).

Muzeum PRL-u. Pobrane z: www.mprl.pl (10.02.2019).

Nuclear threat. Shelters in Nowa Huta (2015). Pobrane z: http:// www.mprl.pl/wystawy/152/nuclear-threat.-shelters-in-nowahuta..html (14.02.2019).

Okoń, W. (1995). Zabawa a rzeczywistość. Warszawa: Wydawnictwo Żak.

Paleczny, T., Kantor, R., Banaszkiewicz, M. (red.) (2012). Kultura zabawy. Kraków: Wydawnictwo Uniwersytetu Jagiellońskiego.

Parry, R. (2013). Museums in a digital age. London: Routledge.

Pasternak, A. (2019). Trasa turystyczna po schronach Nowej Huty - narzędzia i metody projektowania. Światowid, 5, 37-53.

Pfaffenberger, B. (1983). Serious pilgrims and frivolous tourists: The chimera of tourism in the pilgrimages of Sri Lanka. Annals of Tourism Research, 10 (1), 57-74.

Pine, J., Gilmore, J. (1999). The experience economy: Work is theatre an every business a stage. Boston: Harvard Business School Press.

Postman, N. (2000). Amusing ourselves to death: Public discourse in the age of show business. London: Penguin Books.

Poźniak, K. (2014). Nowa Huta: Generations of change in a socialist model town. Pittsburgh: Pittsburgh University Press.

Robinson, M., Picard, D. (red.) (2016). Emotion in motion: Tourism, affect and transformation. London: Routledge.

Salazar, N. (2010). Envisioning eden: Mobilizing imaginaries in tourism and beyond. Oxford: Berghahn Book.

Salwiński, J., Sibila, L.J. (red.) (2008). Nowa Huta - przeszłość i wizja. Studium muzeum rozproszonego. Kraków: Muzeum Historyczne Miasta Krakowa.

Selwyn, T. (red.) (1996). The tourist image: Myths and myth making in tourism. Chichester: John Wiley \& Son.

Smith, L. (2006). Uses of heritage. Oxford: Routledge.

Smith, M., Hall, D. (2006). Enlargement implications for European tourism. W: D. Hall, M. Smith, B. Marciszewska (red.), Tourism in the new Europe: The challenges and opportunities of EU enlargement (s. 32-43). Wallingford: CABI.

Stenning, A., Smith, A., Rochovská, A., Świątek, D. (2010). Domesticating neo-liberalism. Spaces of economic practice and social reproduction in post-socialist cities. Chichester: WileyBlackwell.

Tilden, F. (1957). Interpreting our heritage. Principles and practices for visitor services in parks, museums, and historic places. Chapel Hill: University of North Carolina Press.

Tunbridge, J.E., Ashworth, G.J. (1996). Dissonant heritage: The management of the past as a resource in conflict. ChichesterNew York: Wiley \& Son. 
Urry, J., Larsen, J. (2011). The tourist gaze 3.0. London: Routledge. Whigham, K. (2014). Performing and future (in) performing a past - Identity, cultural performances and the Utopian impulse. Tourist Studies, 14 (2), 203-224.

Xie, P.F. (2015). Industrial heritage tourism. Bristol: Channel View Publications.

Zarzycka, K. (2017). Petny scenariusz wystawy oraz projekt aranżacji wystawy "Trasa turystyczna po schronach Nowej Huty" w pomieszczeniach budynku przy Osiedlu Szkolnym 22 (obecna biblioteka) wraz ze schronem oraz schronach w budynkach na Osiedlu
Szkolnym 9, 37, Osiedlu Krakówiaków 43, realizowanym w ramach projektu "Muzeum PRL - Podziemna Nowa Huta”. Kraków (materiały nieopublikowane, przygotowane na zlecenie Muzeum PRL-u).
Artykuł wpłyną: 20 kwietnia $2019 \mathrm{r}$. Zaakceptowano do druku: 20 maja $2019 \mathrm{r}$. 